Tersedia Online di http://journal2.um.ac.id/index.php/jmsp/

ISSN Online : 2541-4429

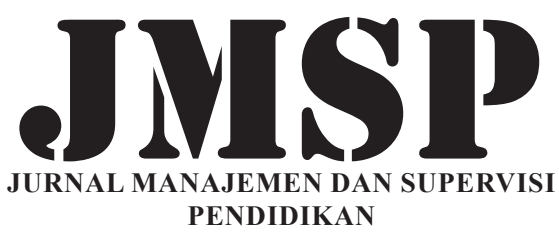

PENDIDIKAN

\title{
ANALISIS KOMPETENSI PEDAGOGIK DOSEN
}

\author{
Yully Kusnadi \\ Universitas Pelita Harapan \\ Jl. Ahmad Yani Dukuh Menanggal Surabaya Jawa Timur Indonesia \\ intuitionkj@gmail.com
}

\begin{abstract}
The research methods used were: qualitative research with a case study approach. The research subjects were five permanent lecturers and one acting director. Data collection methods used in conducting research were in the form of essay questionnaires, multiple choice questionnaires, semi-structured interviews and documents. Based on the results of data analysis, many indicators of lecturer pedagogical competence at the XYZ Nursing Academy were not met. The results of this study provided input for the XYZ Nursing Academy to build lecturer pedagogical competencies. This research would also be empirical evidence about the pedagogical competence of lecturers and suggested to be part of the internal quality assurance system of the XYZ Nursing Academy.
\end{abstract}

Keywords: competency; paedagogic; quality

\begin{abstract}
Abstrak: Penelitian ini bertujuan untuk menganalisis kompetensi pedagogik dosen tetap di Akademi Keperawatan XYZ. Metode penelitian yang digunakan yaitu: penelitian kualitatif dengan pendekatan studi kasus. Subjek penelitian adalah lima dosen tetap dan satu orang pejabat direktur. Pengumpulan data yang digunakan di dalam melakukan penelitian berupa kuesioner esai, kuesioner pilihan ganda, wawancara semi terstruktur dan dokumen. Berdasarkan hasil analisis data, banyak indikator kompetensi pedagogik dosen di Akademi Keperawatan XYZ tidak terpenuhi. Hasil penelitian ini menjadi masukkan bagi Akademi Keperawatan XYZ untuk membangun kompetensi pedagogik dosen. Penelitian ini juga merupakan bukti empiris tentang kompetensi pedagogik dosen dan dapat menjadi bagian dari sistem penjaminan mutu internal dari Akademi Keperawatan XYZ.
\end{abstract}

Kata Kunci: kompetensi; pedagogik; mutu

Akademi Keperawatan XYZ berlokasi di Tangerang, sudah berdiri sejak 1995 dan dikelola oleh Yayasan XYZ. Yayasan XYZ sebagai badan pengelola Akademi Keperawatan XYZ mempekerjakan banyak dosen baru dengan latar belakang pendidikan Sarjana Keperawatan Profesi Ners dan Magister pada bidang ilmu kesehatan lulusan dalam dan luar negeri. Dosen yang dipekerjakan kebanyakan pada usia produktif dan belum mempunyai pengalaman mengajar, ada juga beberapa dosen senior yang sudah memasuki usia pensiun dengan pengalaman puluhan tahun di bidang keperawatan dan kesehatan.

Berdasarkan hasil studi pra kasus yang dilakukan, masalah yang teridentifikasi adalah tingkat kompetensi pedagogik dosen tetap Akademi Keperawatan XYZ. Kualitas dosen yang baik adalah yang bisa mengajar dengan efektif dan menguasai bahan ajar. Pada saat yang bersamaan, dosen juga mengutarakan ketidakyakinan mereka akan kemampuan mereka untuk mengajar secara efektif. Hal ini tentu saja membuat kasus ini mempunyai tingkat urgency untuk ditelaah mengingat kegiatan pembelajaran yang dilakukan terus menerus di Akademi Keperawatan XYZ.

Menurut penjelasan Undang Undang nomor 14 Tahun 2005 mengenai Guru dan Dosen pada penjelasan Pasal 10 ayat 1, kompetensi pedagogik adalah kemampuan mengelola pembelajaran peserta didik. Berdasarkan dasar hukum ini, adalah mutlak bagi semua guru dan dosen untuk menjadi dosen yang berkompetensi dan untuk terus belajar dalam meningkatkan kompetensinya. Kompetensi pedagogik dijabarkan di dalam Peraturan Kementerian Pendidikan Nasional nomor 16 tahun 2007 yang terdiri atas 37 buah kompetensi yang dirangkum dalam 10 kompetensi inti.

Berdasarkan identifikasi masalah yang ada, penelitian ini difokuskan pada analisis tiga kemampuan pedagogik dosen Akademi Keperawatan XYZ, yaitu: penguasaan dosen akan teori belajar dewasa awal 
dan pengaplikasiannya di dalam proses pembelajaran, kemampuan dosen dalam penilaian dan evaluasi proses dan hasil belajar, memanfaatkan hasil dan penilaian evaluasi untuk kepentingan pembelajaran, serta kemampuan dosen untuk melakukan tindakan reflektif untuk peningkatan kualitas pembelajaran. Salah satu penelitian sebelumnya yang mempunyai kesamaan di dalam kasus ini mengemukakan bahwa kompetensi dosen memang sering tidak diberikan perhatian penuh oleh institusi pendidikan. (Sumaryanta, 2018:106). Penelitian ini menggambarkan model penilaian dosen yang telah diterapkan di Indonesia dan tantangannya untuk mendorong pengembangan profesi dosen yang berkelanjutan. Penilaian tersebut digunakan untuk mengukur penguasaan kompetensi pedagogik dan profesional dari dosen.

Berdasarkan hasil wawancara, ditemukan bahwa sebagian besar dosen Akademi Keperawatan XYZ tidak mengetahui cara mendidik remaja dewasa awal yang tentunya berbeda dengan mendidik remaja dan anak-anak. Dosen tidak mengetahui pengetahuan dasar mengenai teori belajar dan mengenal mengenai bermacam-macam teori belajar. Dosen juga didapati kurang mengerti mengenai aplikasi teoriteori belajar di dalam proses pembelajaran yang dilakukan. Selain itu, sebagian besar dosen juga tidak mengetahui tentang pembuatan dan analisis evaluasi proses dan hasil pembelajaran yang sesuai dengan kaidah-kaidah pendidikan seperti cara menulis soal yang baik, soal harus divalidasi terlebih dahulu dan proses pembelajaran yang dievaluasi dengan berkesinambungan. Dosen juga belum pernah melakukan evaluasi atas proses pembelajaran yang dilakukannya. Hal lain yang sangat mengkhawatirkan adalah semua dosen belum mengenal apa itu tindakan reflektif dan belum pernah melakukan tindakan reflektif, seperti mendapatkan feedback tertulis dari mahasiswa mengenai dosen yang merupakan pengampu mata kuliah tersebut dan proses pembelajaran yang dilakukannya. Kasus yang terjadi di Akademi Keperawatan XYZ mempunyai nilai urgency untuk ditelaah untuk mencegah ketidakefektifan di dalam proses belajar mengajar yang terus menerus berlangsung.

\section{METODE}

Penelitian dilaksanakan di Akademi Keperawatan XYZ yang berlokasi di Tangerang dimulai dari Agustus 2018 sampai dengan September 2019. Pendekatan yang digunakan dalam penelitian ini adalah pendekatan kualitatif dengan menggunakan pendekatan studi kasus. Metode penelitian kualitatif dapat diartikan sebagai penelitian yang digunakan untuk meneliti kualitas dari suatu kegiatan atau aktivitas, situasi dan juga material. (Frankael, 2008:6).

Pendekatan studi kasus di dalam pendidikan menggunakan teknik pengumpulan data yang kebanyakan merupakan observasi atas partisipan dalam hal ini subjek, ditambah dengan wawancara yang bersifat formal maupun tidak formal dan evaluasi dokumen. Bogdan dan Biklen (2007:60) menyatakan pendekatan studi kasus berfokus pada organisasi pendidikan yang spesifik seperti sekolah, kampus, pusat rehabilitasi atau sebagian aspek dari organisasi.

Penelitian ini dimulai dengan kegiatan studi pra kasus. Kasus dirumuskan menjadi rumusan masalah. Pengkajian teori penelitian juga dilakukan di dalam proses perumusan masalah. Rumusan masalah yang ada dilanjutkan dengan penyusunan langkah-langkah dalam pengumpulan data dan pembuatan instrumen yang akan merekam kompetensi pedagogik dosen. Data yang ada akan dianalisis untuk menjawab rumusan masalah dan mencapai tujuan penelitian. Instrumen yang telah dibuat, divalidasi sebagai bagian bukti keabsahan di dalam penelitian.

Hasil pengumpulan data kemudian dianalisis melalui proses pengkategorian dan pemberian kode atau coding, penggabungan lalu pendeskripsian untuk membentuk penemuan-penemuan kualitatif dari penelitian studi kasus ini. Berdasarkan penemuan-penemuan kualitatif tersebut dan analisis atas temuan tersebut akan didapatkan jawaban atas rumusan masalah. Setelah pembahasan dari hasil analisis data, kesimpulan dapat ditarik dan saran diberikan. Hasil penelitian merupakan penelitian di Akademi Keperawatan XYZ dan tidak dapat digeneralisasi. 


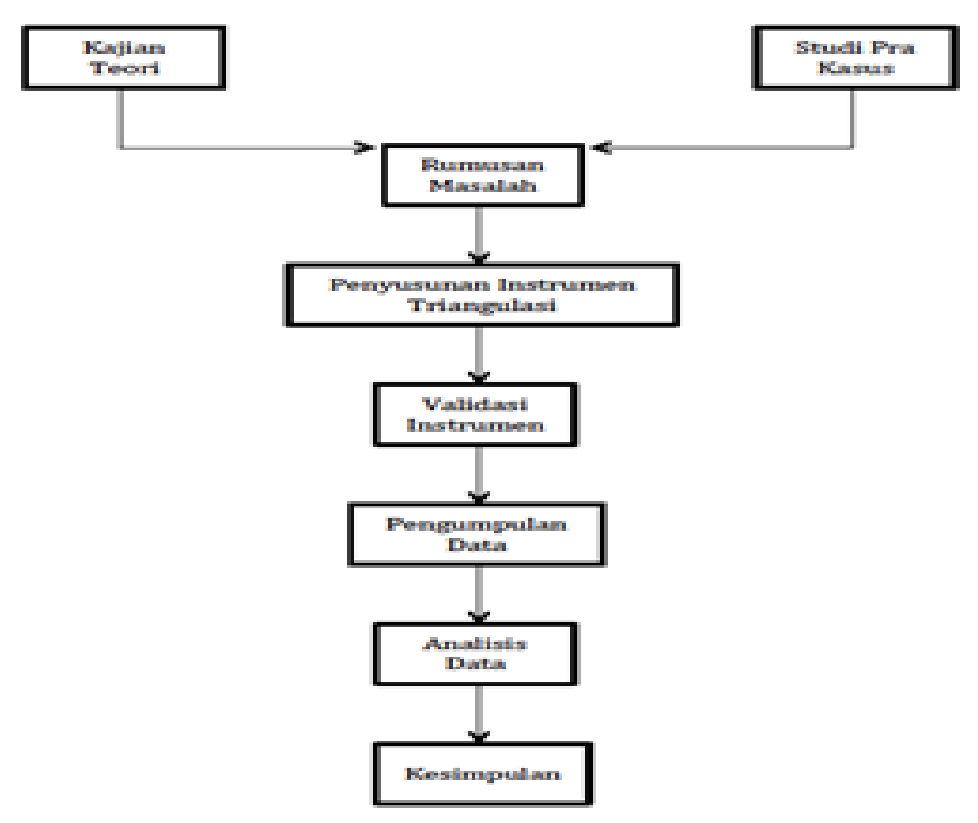

Gambar 1. Prosedur Penelitian

Subjek penelitian adalah lima orang dosen tetap dan satu pejabat direktur Akademi Keperawatan XYZ. Instrumen penelitian yang digunakan untuk mengukur indikator di dalam penelitian ini adalah: lembar kuesioner esai, lembar kuesioner pilihan ganda, lembar daftar guideline pertanyaan wawancara semi terstruktur, lembar rubrik observasi. Proses validasi instrumen penelitian dilakukan dengan meminta persetujuan dari tiga orang validator dengan gelar Magister Pendidikan.

Data primer dikumpulkan dan diolah langsung oleh peneliti di dalam penelitian. Pengumpulan data primer ini menggunakan metode: menjawab kuesioner esai, mengisi kuesioner pilihan ganda, melakukan wawancara semi terstruktur dan melakukan observasi kelas. Data sekunder merupakan data yang dikumpulkan secara tidak langsung oleh peneliti di dalam penelitian. Pengumpulan data sekunder di dalam penelitian ini menggunakan metode: mengumpulkan bukti dokumen. Proses validasi data dilakukan melalui triangulasi metode dan sumber data. Setiap kompetensi

Triangulasi dalam penelitian kualitatif diartikan sebagai pengecekan data dari berbagai sumber yang didapat dengan berbagai cara. Penelitian ini mengunakan triangulasi metode dan sumber data. Analisa data dalam penelitian kualitatif, baik dari kuesioner, wawancara semi terstruktur dan dokumen dikategorikan, dideskripsikan dan digabungkan membentuk penemuan-penemuan kualitatif dari kasus yang sedang diselidiki (Wiersma, 2009:237). Data yang telah terekam di dalam instrumen penelitian studi kasus ini dikategorikan, diberikan kode, digabungkan dan dideskripsikan. Hasil dari proses pengkategorian dan pemberian kode adalah kelompok-kelompok data, berasal dari subjek penelitian yang berbeda tetapi merekam indikator yang sama. Pola akan terlihat ketika data sudah dikategorikan dan diberikan kode, selanjutnya data dari subjek penelitian yang berbeda dengan indikator yang sama digabungkan dan dideskripsikan menjadi hasil pengumpulan data yang siap dianalisa untuk menjawab rumusan masalah dan mencapai tujuan penelitian

\section{HASIL DAN PEMBAHASAN}

Kompetensi penguasaan teori belajar diukur melalui tiga indikator. Indikator 1 yaitu dosen dapat menjelaskan mengenai teori-teori belajar. Indikator 2 yaitu dosen dapat menjelaskan teori belajar yang digunakan sebagai bahan acuan dalam proses pembelajaran. Indikator 3 yaitu dosen dapat menjelaskan aplikasi teori belajar tersebut di dalam proses pembelajaran yang dilakukan. 
Berdasarkan hasil analisis data, Dosen A, B, C, D, E mengetahui definisi belajar tetapi tidak dapat menjelaskan definisi teori belajar dengan tepat di dalam menjawab baik kuesioner esai, kuesioner pilihan ganda dan wawancara. Pengetahuan dosen akan bermacam-macam teori belajar juga tidak terlihat di dalam hasil pengumpulan data. Dosen A, B, C, D, E tidak dapat menjelaskan teori belajar yang dijadikan sebagai bahan acuan di dalam proses pembelajaran yang dilakukan. Dosen dapat menjawab pertanyaan dalam wawancara pada saat topik mengenai aplikasi teori belajar di dalam pembelajaran. Dosen dapat mengartikulasikan pengaplikasian dari teori belajar di dalam kegiatan pembelajaran mereka. Mereka menggunakan pengalaman mereka di masa lalu ketika mereka juga menjadi mahasiswa keperawatan dan juga menggunakan naluri mereka sebagai dosen. Dosen Akademi Keperawatan XYZ tidak menguasai kompetensi penguasaan teori belajar dewasa awal walaupun dosen mampu mendeskripsikan praktik pembelajaran yang sesuai dengan perkembangan dewasa awal.

Kompetensi melakukan penilaian dan evaluasi proses dan hasil pembelajaran dan memanfaatkan hasil penilaian dan evaluasi untuk kepentingan pembelajaran diukur melalui tiga indikator. Indikator 1 yaitu dosen dapat melakukan penilaian dan evaluasi proses pembelajaran. Indikator 2 yaitu dosen dapat melakukan penilaian dan evaluasi hasil pembelajaran. Indikator 3 yaitu dosen dapat memanfaatkan hasil penilaian dan evaluasi proses dan hasil pembelajaran.

Berdasarkan hasil analisis data, didapatkan bahwa semua dosen tidak mengetahui tentang evaluasi proses di dalam pembelajaran dan belum pernah melakukan evaluasi yang sistematik dan berkesinambungan pada proses pembelajaran yang mereka lakukan. Analisis data juga menunjukkan dosen mengetahui mengenai evaluasi hasil belajar dan melakukan penilaian dan evaluasi hasil belajar secara rutin. Dosen melakukan penilaian dan evaluasi belajar pada tengah semester berupa Ujian Tengah Semester (UTS) dan pada akhir semester berupa Ujian Akhir Semester (UAS). Tetapi dosen tidak pernah melakukan uji validitas dan analisis terhadap butir soal yang dibuat untuk UTS dan UAS tersebut. Kemampuan Dosen memanfaatkan hasil penilaian dan evaluasi hasil pembelajaran dengan memberikan kegiatan "review" terekam di dalam wawancara dari beberapa dosen. Tetapi tidak ada dokumen yang mendokumentasikan kegiatan akademik tersebut. Hal ini sangat disayangkan mengingat perlunya kegiatan pendokumentasian yang terstruktur. Kompetensi melakukan tindakan reflektif dan memanfaatkannya untuk peningkatan kualitas pembelajaran diukur melalui indikator, yaitu: dosen dapat melakukan tindakan reflektif untuk peningkatan kualitas pembelajaran.

Berdasarkan hasil analisis data, dosen Keperawatan XYZ mengerti konsep dasar dari kata reflektif tetapi belum dapat menggali lebih dalam mengenai tindakan reflektif sebagai bagian dari kegiatan proses pembelajaran. Tidak terdapatnya dokumentasi dari tindakan reflektif di dalam proses pembelajaran menandakan bahwa dosen belum pernah melakukan tindakan reflektif yang terdokumentasi dan sistematik atau terstruktur. Pada hasil analisis wawancara Pejabat Direktur, ditemukan bahwa tindakan reflektif tidak dikenal di dalam sistem pembelajaran di Akademi Keperawatan XYZ. Padahal kemampuan melakukan tindakan reflektif adalah kompetensi yang wajib dimiliki oleh setiap dosen, seperti yang diungkapkan Brockbank dan McGill (2007:87) terdapat tiga manfaat yang menjadikan alasan bagi dosen untuk mempunyai kemampuan ini: dosen akan berkemampuan untuk belajar dari pembelajaran mereka sendiri dan berkesempatan untuk berkembang di dalam praktek pembelajarannya, dosen juga akan memberikan kesempatan untuk mahasiswa juga belajar melakukan tindakan reflektif dengan mencontoh dosen dan mendorong mahasiswa untuk belajar mengenai tindakan reflektif dan mengaplikasikannya ke dalam proses pembelajaran pribadi mahasiswa.

\section{SIMPULAN DAN SARAN}

\section{Simpulan}

Kesimpulan yang dapat ditarik dari hasil analisis data adalah dosen tidak mengetahui secara tepat definisi, cakupan dan aplikasi dari teori belajar. Dosen cenderung mengaplikasikan teori belajar di dalam proses pembelajarannya berdasarkan naluri seorang dosen dan berdasarkan pengalaman ketika 
mereka sebagai mahasiswa. Dengan tidak dimengertinya teori belajar dengan baik, maka secara praktik di dalam proses pembelajaran, dikhawatirkan akan terjadi ketidaksesuaian antara kebutuhan belajar mahasiswa dengan metode, teknik dan strategi yang digunakan oleh dosen. Kemampuan dosen Akademi Keperawatan XYZ di dalam penguasaan teori belajar belum mencapai standar kompetensi pedagogik yang diatur dalam Peraturan Kementerian Pendidikan Nasional nomor 16 tahun 2007.

Berdasarkan pembahasan, dosen Akademi Keperawatan XYZ tidak mengerti mengenai evaluasi proses secara utuh dari proses awal hingga akhir pembelajaran. Berdasarkan hasil analisis pengumpulan data, dosen Akademi Keperawatan XYZ terlihat tidak mengetahui kegiatan evaluasi proses di dalam proses pembelajarannya. Kelalaian dalam melakukan evaluasi, lambat laun dikhawatirkan akan mempengaruhi efektivitas dan kualitas dari proses pembelajaran yang pada akhirnya akan mempengaruhi kualitas lulusan. Akademi Keperawatan XYZ memerlukan sistem untuk mengevaluasi proses pembelajaran dan mensosialisasikannya kepada semua Dosen.

Berdasarkan hasil analisis data, dosen dapat melakukan evaluasi dan penilaian hasil belajar, terutama yang bersifat rutin berupa Ujian Tengah Semester (UTS) dan Ujian Akhir Semester (UAS). Hanya saja, kekurangan di dalam pendokumentasian, kegiatan remedial disebut di dalam beberapa hasil wawancara semi terstruktur tetapi tidak didukung oleh bukti dokumentasi. Pemanfaatan evaluasi dan penilaian akan hasil belajar dengan membuat program remedial bagi mahasiswa yang membutuhkan akan memberikan kesempatan kepada mahasiswa untuk mendapatkan proses pembelajaran yang lebih spesifik, sesuai dengan gaya belajarnya untuk menjawab kesulitan belajar yang dialaminya. Dokumentasi membantu dosen dan mahasiswa untuk mengidentifikasi keefektifan metode remedial tertentu terhadap spesifik kelompok mahasiswa. Hal ini tentu saja, akan membangun kualitas akademik Akademi Keperawatan XYZ yang student centered. Kemampuan dosen Akademi Keperawatan XYZ di dalam melakukan evaluasi proses dan hasil belajar dan memanfaatkannya untuk kepentingan pembelajaran belum mencapai standar kompetensi pedagogik yang diatur dalam Peraturan Kementerian Pendidikan Nasional nomor 16 tahun 2007.

Berdasarkan hasil analisis data dan pembahasan, dosen Akademi Keperawatan XYZ belum mempunyai pengertian yang komprehensif mengenai tindakan reflektif dan tujuan dari tindakan. Kondisi ini pun dikonfirmasi oleh Pejabat Direktur merangkap Wakil Direktur bagian Akademik yang juga menyatakan tidak adanya kebijakan dari Akademi Keperawatan XYZ untuk melakukan tindakan reflektif di dalam proses pembelajaran, juga ketidaktahuannya mengenai tindakan reflektif. Beberapa dosen Keperawatan XYZ mengerti konsep yang sangat dasar dari reflektif dan tidak mempunyai pengertian lebih dalam mengenai tindakan reflektif sebagai bagian integral dari kegiatan proses pembelajaran. Tindakan reflektif yang terdokumentasi dan sistematik atau terstruktur akan memberikan dampak yang sangat positif bagi proses pembelajaran baik dan juga pertumbuhan setiap individu sebagai manusia yang maju. Mahasiswa akan belajar secara langsung untuk mempunyai pemikiran yang terbuka dan mampu melihat diri sendiri secara jujur. Dosen yang melakukan tindakan reflektif akan memberikan contoh secara langsung mengenai evaluasi diri. Kemampuan dosen Akademi Keperawatan XYZ di dalam melakukan tindakan reflektif dan memanfaatkannya untuk kepentingan pembelajaran belum mencapai standar kompetensi pedagogik yang diatur dalam Peraturan Kementerian Pendidikan Nasional nomor 16 tahun 2007.

\section{Saran}

Bagi Yayasan XYZ mendorong dan mendukung Akademi Keperawatan XYZ untuk membuat program yang bertujuan untuk meningkatkan kompetensi pedagogik dosen. Juga untuk mendukung kegiatan penelitian untuk meneliti kompetensi dosen di masa depan untuk memastikan kualitas proses pembelajaran yang terjamin. Untuk Akademi Keperawatan XYZ membuka kesempatan bagi dosen untuk meningkatkan kompetensi pedagogiknya, dengan mengadakan seminar, workshop dan pelatihan dengan topik pedagogik yang dilaksanakan di dalam lingkungan akademi. Juga untuk menciptakan kesadaran pentingnya kompetensi pedagogik untuk dimiliki oleh para dosen dan mulai mengintegrasikan tindakan reflektif ke dalam proses pembelajaran. Saran bagi dosen untuk berinisiatif meningkatkan kompetensi 
pedagogiknya.

Sebaiknya penelitian selanjutnya di Akademi Keperawatan XYZ melibatkan lebih banyak dosen tetap. Dan juga melibatkan mahasiswa sebagai subjek penelitian. Juga, kompetensi yang diteliti mencakup lebih banyak lagi kompetensi pedagogik dan juga mencakup kompetensi lainnya seperti: kompetensi profesional, kompetensi sosial dan kompetensi kepribadian. Penelitian sebaiknya dilakukan dalam rentang waktu lebih panjang sehingga dapat lebih dalam lagi merekam indikator-indikator di dalam lebih banyak lagi di dalam

\section{DAFTAR RUJUKAN}

Brockbank, A \& McGill, I.(2007). Facilitating Reflective Learning in Higher Education. New York: Two Penn Plaza.

DPR RI. (2005). Undang Undang Republik Indonesia Nomor 14 Tahun 2005 Tentang Guru dan Dosen. Jakarta: Dewan Perwakilan Rakyat.

Kemendiknas. (2006). Peraturan Menteri Pendidikan Nasional Nomor 16 Tahun 2007 Tentang Standar Kualifikasi Akademik dan Kompetensi Guru. Jakarta: Kementerian Pendidikan Nasional.

Frankel, R., Wallen, N.E., \& Hyun, H.H. (2008). How to Design and Evaluate Research in Education. New York: Avenue of Americas.

Bogdan, R. C., \& Biklen, S.K. (2007) Qualitative Research for Education: An Introduction to Theories and Methods. USA: Arlington Street.

Sumaryanta., Djemari, M., Sugiman., \& Tutut, H. (2018). Assessing Teacher Competence and Its Follow-up to Support Professional Development Sustainability. Journal of Teacher Education for Sustainability. Vol: 20, Number 1: 106.

Willliam, W. (2009). Research Methods in Education: An Introduction. Boston: 75 Arlington Street.

Yayasan XYZ. (2017). Statuta Akademi Keperawatan XYZ. Tangerang: Yayasan XYZ. 